\title{
State of the art in the theoretical study of the high-frequency stability of working processes in liquid-propellant rocket combustion chambers
}

\author{
Institute of Technical Mechanics \\ of the National Academy of Sciences of U kraine and the State Space Agency of U kraine \\ 15 Leshko-Popel St., Dnipro 49005, U kraine; e-mail: khoryak@i.ua
}

In the tryout of liquid-propellant rocket engines (LPREs), the parameters that govern working processes in the LPRE systems (the pressure, the flow velocity, the gas and liquid temperature, the turbopump speed, etc.) exhibit low- and high-frequency oscillations. High-frequency oscillations in a combustion chamber, which are potentially dangerous to the LPR operational reliability and integrity, are the least understood. The mos important tool in the study and development of measures aimed at their elimination in the flight of liquidpropellant launch vehicles is a mathematical simulation of high-frequency processes in a combustion chamber.

This paper overviews recent publications and analyzes the state of the art in the numerical study of highfrequency dynamic processes in LPRE combustion chambers with the aim to assess the possibility of using the available numerical methods to simulate the above-mentioned processes in the problem of theoretical prediction of LPRE high-frequency stability and the combustion chamber pressure and flow rate oscillation amplitudes. Consideration is given to the currently adopted mechanisms of high-amplitude oscillations in the LPRE systems involving the dynamic interaction of physical and chemical processes in the mixing and combustion zone in conditions of periodical heat removal under the action of acoustic oscillations and turbulence in the flow and combustion of the propellant components and combustion products.

The analysis conducted shows that the methods of mathematical simulation of high-frequency acoustic oscillations in an LPRE can be divided into three basic groups: methods for the calculation of the acoustic oscillation parameters in cylindrical chambers based on analytical mathematical models of a relatively low order with the use of the Bessel functions, methods for the study of thermoacoustic phenomena using approaches of computational fluid dynamics, and hybrid methods, in which combustion dynamics is calculated separately from the combustion product acoustic oscillation parameters. The main results obtained in the framework of the abovementioned groups are overviewed. The advantages and drawbacks of the numerical study of combustion product thermoacoustic oscillations in LPRE chambers are analyzed.

Keywords liquid-propellant rocket engine, combustion chamber, self-oscillations, high-frequency thermoacoustic instability, vibration combustion, Crocco mechanism, CF D methods of gas dynamics.

1. Glikman B. F. Automatic Control of Liquid-Propellant Rocket Engines. 2nd edition. Moscow: Mashinostroyeniye, 1989.96 pp. (in Russian).

2. Glikman B. F. Automatic Control of Liquid-Propellant Rocket Engines. Moscow: Mashinostroyeniye, 1974. 396 pp. (in Russian).

3. Koroteev A. S. Working Processes in a Liquid-Propellant Rocket Engine and Simulation Thereof. Moscow: Mashinostroyeniye, 2009. 511 pp. (in Russian).

4. Mechanical Engineering. Encyclopaedia. In 40 volumes. K. V. F rolov (Chf. Ed.). Space-Rocket Hardware. V. IV-22. A. P. Adzhyan, E. A kim., O. M. Alifanov et al: Legostaev V. P. (E d.). In 2 books. Book 1. Moscow: Mashinostroyeniye, 2012. 925 pp. (in Russian).

5. Pylypenko O. V., Prokopchuk A. A., Dolgopolov S. I., Khoryak N. V., Nikolaev A. D., Pisarenko V. Yu. Kovalenko V. N. Mathematical simulation and stability analysis of low-frequency processes in a sustainer liquid-propellant rocket engine with generator gas afterburning. Vestnik Dvigatelestroyeniya. 2017. No. 2. Pp. 34-42. (in Russian).

6. Pylypenko O. V., Prokopchuk A. A., Dolgopolov S. I., Pisarenko V. Yu., Kovalenko V. N., Nikolaev A. D., Khoryak N. V. Peculiarities of mathematical modeling of low-frequency dynamics of the staged liquid rocket sustainer engines at its startup Space Sci. \& Technol. 2017. V. 23. No. 5. Pp. 3-12. (in Russian).

7. Pilipenko V. V., Zadontsev V. A., Natanzon M.S. Cavitation Self-Oscillations and Hydrosystem Dynamics. Moscow: Mashinostroyeniye, 1977. 352 pp. (in Russian).

8. Pilipenko V. V. Cavitation Self-Oscillations. Kiev: Naukova Dumka, 1989. 316 pp. (in Russian).

9. Pilipenko V. V., Dolgopolov S. I. Experiment-calculation determination of the coefficients of an equation of cavity dynamics in inducer-equipped centrifugal pumps of various standard sizes. Teh. Meh. 1998. No. 8. Pp. 50-56. (in Russian).

10. Dolgopolov S. I. Hydrodynamic model of cavitation oscillation for modelling dynamic processes within pump systems at high cavitation number. Teh. Meh. 2017. No. 2. Pp. 12-19. (in Russian). 
11. Khoryak N. V., Nikolaev A, D. Decomposition and stability analysis of a dynamic system consisting of feed pipelines and a sustainer liquid-propellant rocket engine with generator gas oxidizing afterburning. Teh. Meh. 2007. No. 1. Pp. 28-42. (in Russian).

12. Khoriak N. V., Dolhopolov S. I. Features of mathematical simulation of gas path dynamics in the problem of the stability of low-frequency processes in liquid-propellant rocket engines. Teh. Meh. 2017. No. 3. Pp. 3044. (in Russian).

13. Gemranova E. A., Kolbasenkov A. I., Koshelev I. M., Levochkin P. S., Martirosov D. S. Ways to suppress low-frequency osciilations in a highly throttled liquid-propellant rocket engine. V. P. Glushko NPO Energomash (Khimki). 2013. No. 30. Pp. 104-110. (in Russian).

14. Belyaev E. N., Kolomentsev A. I., Nasimento L. B., Nazarov V. P. Effect of the design parameters of a flow regulator on its static and dynamic performance. Vestnik SibGAU. 2014. No. 1 (53). Pp. 109-113. (in Russian).

15. Lebedinsky E, V., Zaitsev B. V., Sobolev A. A. Multilevel mathematical simulation of a flow regulator for a liquid-propellant rocket engine. State Scientific Center "Keldysh Research Center." Moscow. 2011.10 pp. URL: http://www.lpre.de/resources/articles/reg_model.pdf. (in Russian).

16. Dolgopolov S. I., Nikolaev A. D. Mathematical modelling low-frequency dynamics of flow controller at various amplitudes of harmonic disturbance. Teh. Meh. 2017. No. 1. Pp. 15-25. (in Russian).

17. Koshelev I. M., Martirosov D. S., Kolbasenkov A. I. Effect of the condensation of a high-temperature oxidizing gas in the cryogenic oxygen zone on the low-frequency stability of a liquid-propellant rocket engine. Dvigatel. 2012. No. 6(84). Pp. 24 - 27. URL: http: //engine.aviaport.ru/issues/84/pics/pg24.pdf. (in Russian).

18. Natanzon M. S. Pogo Self-Oscillations of a Liquid-Propellant Rocket. Moscow: Mashinostroyeniye, 1977. 208 pp. (in Russian).

19. Pilipenko V. V., Dovgot'ko N. I., Dolgopolov S. I., Nikolaev A .D., Serenko V. A., Khoryak N. V. Theoretical evaluation of the amplitudes of pogo vibrations in liquid propellant launch vehicles. Kosm. Nauka Tehnol. 1999. No. 5(1). Pp. 90-96. (in Russian).

20. Shevyakov A. A., Kalnin V. M., Naumenkova M. V., Dyatlov V. G. Theory of Rocket Engine Automatic Control. Moscow: Mashinostroyeniye, 1978. 288 pp. (in Russian).

21. Harrje D. T., Reardon F. H. et al. Combustion Instability in Liquid-Propellant Rocket Engines. Moscow: Mir, 1975. (in Russian).

22. Raushenbakh B. V. Vibration Combustion. Moscow: Fizmatgiz, 1961. 500 pp. (in Russian).

23. Natanzon M. S. Combustion Instability. Moscow: Mashinostroyeniye, 1986. (in Russian).

24. Degtyarev A. V. Space Technology. Problems and Prospects. Dnipropetrovsk: ART-PRESS, 2014. 420 pp. (in Russian).

25. Larionov V. M., Zaripov R. G. Gas Self-Oscillations in Plants with Combustion. Kazan: Kazan State Technical University, 2003. 227 pp. (in Russian).

26. Kochetkov Yu. M. Turbulence. Onset of instability in a liquid-propellant rocket engine. Dvigatel. 2012. No. 2(80). Pp. 30-32. URL: www.dvigately.ru. (in Russian).

27. Kochetkov Yu. M. Turbulence and self-oscillation process in a liquid-propellant rocket engine. Dvigatel. 2012. No. 3(81). Pp. 32-34 www.dvigately.ru. (in Russian). ‘

28. Gotsulenko V. V., Gotsulenko V. N. Self-oscillations of vibration combustion in a liquid-propellant rocket engine self-excited due to a phenomenological delay in propellant combustion and mathematical simulation thereof. Mayematicheskoe Modelirovanie. 2008. No. 3(15). Pp. 39-42. (in Russian).

29. Crocco L. On the role of the delay time in the excitation of longitudinal high-frequency oscillations in the combustion chamber of a liquid-propellant rocket engine. Voprosy Raketnoi Tekhniki. 1959. No. 5. Pp. 2429. (in Russian).

30. Crocco L., Cheng S.-I. High frequency combustion instability in rockets with distributed combustion. Fourth Symposium (International) on Combustion. 1953. V. 4. Pp. 865-880.

31. Crocco L., Cheng S.-I. Theory of Combustion Instability in Liquid-Propellant Rocket Engines. Moscow: Inostrannaya Literatura, 1958. 351 pp. (in Russian).

32. Makhin V. A. Prisnyakov V, F., Belik N. P. Dynamics of Liquid-Propellant Rocket Engines. Moscow: Mashinostroyeniye, 1969. 834 pp. (in Russian).

33. Mark L. Dranovsky. Combustion Instabilities in Liquid Rocket Engines: Testing and Development Practices in Russia. American Institute of Aeronautics and Astronautics. P. 322. URL: https://doi.org/10.2514/4.866906

34. Vullis L. A., Ershin Sh. A., Yarin L. P. Basics of Gas Flare Theory. Leningrad: Energia, 1968. 250 pp. (in Russian).

35. Zhiguo Zhanga, Dan Zhaob, Nuomin Hanb, Shuhui Wangc, J unwei Lid. Control of combustion instability with a tunable Helmholtz resonator. Aerospace Science and Technology. 2015. No‘. 41. Pp. 55-62.

36. Laudein E., Pongratz R., Piero R., Preclik D., Yang V. Anderson W.E. (Eds.). Experimental Procedures Aiding the Design of Acoustic Cavities in Liquid Rocket Engine Combustion Instability. Progress in Astronautics and Aeronautics. AIAA. Washington D . 1995. V. 169 . hap. 14. Pp. 377-399.

37. Harrje D., Reardon F. Liquid Rocket Engine Combustion Instability. NASA-SP-194. 1972. 657 pp.

38. Bell W. A., Zinn B. T. The Prediction of Three-Dimensional Liquid-Propellant Rocket Nozzle Admittances. NASA. Tech. Report NASA-CR-121129. $1973 . \quad 68$ pp. https://ntrs.nasa.gov/search.jsp?R=19730009080 
39. Koeglmeier S., Kaess R., Morgenweck D., Vollmer K., Kathan R., Sattelmayer T. Rapid approach for the prediction of complex acoustic resonance frequencies in rocket combustion chambers. 2nd REST Modeling Workshop. 2010. 12 pp.

40. Crocco L. Theoretical studies on liquid propellant rocket instability. Tenth Symposium (International) on Combustion. 1965. Pp. 1101-1128.

41. Pirk Rogerio, d'Andrade Souto Carlos, Donizeti da Silveria Dimas, Candido Magno de Souza, Luiz Carlos Sandoval Goes. Liquid rocket combustion chamber acoustic characterization. Journal of Aerospace. Technology and Management. 2010. V. 2, No. 3. Pp. 269-278.

42. Lebedinsky E. V., Cho Gyu Sik. Antipulsation baffle plates as a means to control combustion instability in combustion chambers. All-Russian Scientific-Technical Journal "Polyot.” 2007. Pp. 42-47. (in Russian).

43. Mosolov S. V., Sidlerov D. A. Numerical study of the effect of antipulsation baffle plates on the working process development in the combustion chamber of an oxygen-kerosene liquid-propellant rocket engine with centrifugal jet injectors. Herald of the Bauman Moscow State Technical University. Series Mechanical Engineering. 2017. No. 2 (113). URL: https://cyberleninka.ru/article /n/issledovanie-vliyaniyaantipulsatsionnyh-peregorodok-na-razvitie-rabochego-protsessa-v-kamere-sgoraniya-kislorodnokerosinovogo-zhrd-s (last accessed on Dec. 10, 2019). (in Russian).

44. Mitchell C. E., Espander W. R. Combustion Instability with Partial Length Acoustic Liners. NASA-CR14-1131. 1973. URL: https://ntrs.nasa.gov/search.jsp?R=19750005853 2020-05-25T08:10:27+00:00Z

45. Borghi R., Lacas F. Modeling of liquid-propellant spray combustion in rocket engine combustion. 2nd International Symposium on Liquid Rocket Propulsion. ONERA-Chatillon, France. June 19-21, 1995. Pp. 7 $1-7-26$.

46. Gerhold T., Friedrich 0., Evans J., Galle M. Calculation of Complex Three-Dimensional Configurations Employing the DLR-TAU-Code. AIAA. 1997. Paper 97-0167. URL: https://doi.org/10.2514/6.1997-167

47. Oschwald Mich., Faragó Zoltán, Searby Geoff, Cheuret Fr. Resonance Frequencies and Damping of a Combustor Acoustically Coupled to an Absorber. Journal of Propulsion and Power. 2008. Vol. 24 , No. 3. May-June 2008. Pp. 524-532.

48. Anderson J. D. Computational Fluid Dynamics. The basics with applications. McGraw-Hill Education. 1st edition. 1995.574 pp.

49. Yang V., Lafon P. Liquid propellant droplet vaporization and combustion. 2nd International Symposium on Liquid Rocket Propulsion. ONERA-Chatillon, France. June 19-21, 1995. p. 8-1-8-16.

50. Chen C. P., C hen Y. S. Modeling of turbulent mixing in liquid-propellant spray. 2nd International Symposium on Liquid Rocket Propulsion. ONERA-Chatillon, France. June 19-21, 1995. p. 7-1-7-26.

51. Gutheil E., Schlots D. Numerical approaches to spray combustion. 4th Symposium on Liquid Space Propulsion. DLR/Lmp. Germany, March 13-15, 2000. 12 pp.

52. Tucker P. K., Shee W. A. Global optimization methodology for GO2/GH2 single element injector design. 4th Symposium on Liquid Space Propulsion. DLR/Lmp. Germany, March 13-15, 2000. 13 pp.

53. Novikov A. V., Yagodnikov D. A., Burkaltsev V. A., Lapitsky V. I. Mathematical model and calculation of the characteristics of the working process in the combustion chamber of a low-thrust methane-oxygen liquidpropellant rocket engine. Herald of the Bauman Moscow State Technical University. Special issue "Today's Rocket Production Theory and Practice." 2004. Pp. 8-17. (in Russian).

54. Kalmykov G. P., Larionov A. A., Sidlerov D. A., Yanchilin L. A. Numerical simulation and investigation of working process features in high-duty combustion chambers. Journal of Engineering Thermophysics. 2008. V. 17. No. 3. Pp. 196-217.

55. Magnussen B. F., Hjertager B. H. On Mathematical Modeling of Turbulent Combustion with Special Emphasis on Soot Formation and Combustion. 16th Symp. (Int.) on Combustion. The Combustion Institute. 1976. $719 \mathrm{pp}$.

56. Gosman A. D., Ioannides E. Aspects of Computer Simulations of Liquid-Fuelled Combustors. AIAA. 1981. $81 \mathrm{pp}$.

57. Mostafa A. A., Mongia H. C. On the Turbulence-Particles Interaction in Turbulent Two-Phase Flows. AIAA. 1986. Paper No. AIAA-86-0215. URL: https://doi.org/10.2514/6.1986-215

58. Khalil E. E., Spalding D .B., Whitelaw J. H. The calculation of local flow properties in two-dimensional furnaces. Int. J. Heat Mass Transfer. 1975. V. 18. No. 16. p. 775-791.

59. Panankar S. Numerical Methods for the Solution of Heat Exchange and Fluid Dynamics Problems. Moscow: Energoatomizdat, 1984. 148 pp. (in Russian).

60. Van-D oormaal J. P., Raithby G. D. Enhancements of the SIMPLE method for predicting incompressible fluid flows. Numerical Heat Transfer. 1984. V. 67. p. 147-163.

61. Patankar S. V. Recent developments in computational heat transfer. J. of Heat Transfer. 1988. V. 110. Iss. 4b. Pp. 1037-1045.

62. Karki K .C., Mongia H. C. Recent Developments in Computational Combustion Dynamics. AIAA. 1989. Paper No. AIAA-89-2808.

63. Kalmykov G .P., Larionov A. A., Sidlerov D. A., Yanchilin L. A. Numerical simulation of operational processes in the combustion chamber and gas generator of oxygen-methane liquid rocket engine. TORUS PRESS. EUCASS book Progress in Propulsion Physics. 2009. V. 1. Section Liquid and Gelled Rocket Propulsion. Pp. 185-204.

64. M osolov S. V., Sidlerov D. A., Ponomarev A. A., Smirnov Yu. L. Computational study of the working process features in oxygen-hydrocarbon liquid-propellant rocket engine combustion chambers. Trudy MAI. 2012. No. 58. 10 pp. URL: www.mai.ru/science/trudy/ (in Russian). 
65. Mosolov S. V., Sidlerov D. A., Ponomarev A. A. Numerical comparative analysis of the working process features in combustion chambers of liquid-propellant rocket engines with jet-jet and centrifugal jet injectors. Trudy MAI. 2012. No. 59. 9 pp. URL: http://trudymai.ru/published. php?ID=34989. (in Russian).

66. Sidlerov D. A., Ponomarev A. A. Numerical simulation of the evaporation and burning of propellant droplet jets in liquid-propellant rocket engine combustion chambers. Trudy MAI. 2014. No. 77. Pp. 62-73. (in Russian).

67. Kaess R., Koeglmeier S., Sattelmayer T., Schulze M., Oschwald M., Hardi J. HF combustion stability research activities in Germany.-SP2016_3124816 - Space Propulsion Conference. Rome. 2016. 12 pp. URL: https://elib.dlr.de/107846/1/Kaess2016_SP2016_3124816.pdf

68. Banuti D. Thermodynamic Analysis and Numerical Modeling of Supercritical Injection. Ph.D. Dissertation, University of Stuttgart. Stuttgart. 2014. 195 pp. URL: https://www.researchgate.net/publication/279381888

69. Mühlbauer B., Ewert R., Kornow O., Noll B. Evaluation of the RPM approach for the simulation of broadband combustion noise. AIAA paper. 2010. V. 48, No. 7. Pp 1379-1389.

70. Karl S., Lüdeke H. Application of the DLR Tau code to predict acoustic damping rates in generic combustion chamber configurations. DLR-Interner Bericht. DLR IB 224-2012 A67. 2012.11 pp. URL: https://www.researchgate.net/scientific-contributions/75359824_Sebastian_Karl. URL in elib: https:// elib.dlr.de/77563/

71. Beinke S., Dally B., O schwald M. Modelling Acoustic Excitation for the Simulation of Combustion Instability Experiments. 18th Australasian Fluid Mechanics Conference Launceston. Australia. 3-7 December 2012. URL: https://people.eng.unimelb.edu.au/imarusic/proceedings/18/167\%20-\%20Beinke.pdf

72. Douglas G. Talley, Suresh Menon Douglas. Engine Level Simulation of Liquid Rocket Combustion Instabilities. AFPRD32132C5I, Air Force Research Laboratory, USA. 8 pp. URL: https://apps.dtic.mil/sti/pdfs/ADA596950.pdf

73. Schulze M., Schmid M., Morgenweck D., Koeglmeier S., Sattelmayer T. A. Conceptional approach for the prediction of thermoacoustic stability in rocket engines. 49th AIAA/ASME/SAE/ASEE Joint Propulsion Conference. 2013. 11pp.

74. Koeglmeier S., Kaess R., Sattelmayer T. Modelling of acoustic absorbers for liquid rocket combustion chambers. Space Propulsion Conference. 2014. URL: https://mediatum.ub.tum.de/1231959

75. Schulze M., Sattelmayer T. Linear stability assessment of a cryogenic rocket engine. International Journal of Spray and Combustion Dynamics. 2017. V. 9. No. 4. Pp. 277-298.

76. Kaess R., Braun J., Behr R. Calculation of HF Eigenmodes in Liquid Rocket Combustion Chambers. Germany. Munich. Airbus Safran Launchers. 5 pp. URL: https://dokumen.tips/ download/link/calculation-of-hf-eigenmodes-in-liquid-rocket-combustion-of-hf-eigenmodes-in

77. Cordioli J. A., Cotoni V. Applications of the hybrid FE-SEA method to vibroacoustic analysis of complex engineering structures. CA 92130. 20th International Congress of Mechanical Engineering. Gramado, RS, Brazil .November 15-20, 2009. 10 pp.

78. Bui T., Schröder W., Meinke M. Numerical analysis of the acoustic field of reacting flows via acoustic perturbation equations. Computers \& Fluids. 2008. No. 37(9). Pp. 1157-1169.

79. Shorin V. P. et al. Acoustic Methods and Means for Pressure Pulsation Measurements. Samara: Samara State Aerospace University, 2007. 132 pp. (in Russian).

80. K oeglmeier S., Kaess R. Evaluation of thermo-acoustic stability behavior in full-scale liquid rocket propulsion systems. 8th European Conference for Aeronautics and Aerospace Sciences (EUCASS). 2019. 15 pp.

81. Weier H., Schodl P. Development and testing of various methods for pulsating pressure measurement in turbomachines. Trudy ASME. Series D. 1971. No. 4. Pp. 131-138. (in Russian).

82. Dolgolenko G. P., Dedesh V. T., Leut A. P. et al.; Dolgolenko G. P. (Chf. Ed.). Flight Tests of Special Devices and Systems of Aircraft and Helicopter Power Plants. Moscow: Mashinostroyeniye, 1984. 128 pp. (in Russian).

83. Plotnikov I. V., Polukhin G. P., Shumilin V. P. State of the art and problems in variable pressure measurement assurance. Metrologiia. 1976. No. 4. Pp. 19-25. (in Russian).

84. Andriyankin 0. A. Means for pulsating pressure measurement in an aircraft air intake duct under bench conditions. Voprosy Aerodinamiki Letanelnykh Apparatov. 1975. No. 323. Pp. 81-88. (in Russian).

85. Boikov N. A., Zvezdin P. S., Reznik L. B. Pressure Measurement in Fast Processes. Moscow: Energia, 1970. 62 pp. (in Russian).

86. Vashny E. M. Measuring Circuit Dynamics. Moscow: Energia,1969. 288 pp. (in Russian).

87. Bogdanov V. V., Kukinov A. E., Khvostova A. K. et al. Effect of flow pulsations in aircraft air intakes on the turbojet compressor operation. TsAEI Review No. 400. Moscow: TsAEI, 1973. 166 pp. (in Russian).

88. Vyalkov A. V., Zimenkov E. V. Overview of pressure measurement methods and means. Trudy TsIAM. 1988. No. 1258. Pp. 25-30. (in Russian).

89. Zalmanzon L. A. Aerohydrodynamic Methods for Automatic System Input Parameter Measurement. Moscow: Nauka, 1973. 464 pp. (in Russian).

Received on, in final form on 